\title{
Simulated drought regimes reveal community resilience and hydrological thresholds for altered decomposition
}

Héctor Rodríguez Pérez"\#, Guillaume Borrel2,‡, Céline Leroy³, Jean-François Carrias², Bruno Corbara², Diane S. Srivastava ${ }^{4}$, Régis Céréghino ${ }^{5}$

${ }^{1}$ CNRS, Ecologie des Forêts de Guyane (AgroParisTech, CIRAD, INRA, Université de Guyane, Université des Antilles), Campus Agronomique, F-97379 Kourou cedex, France

${ }^{2}$ Université Clermont Auvergne, CNRS, Laboratoire Microorganismes: Génome et Environnement, F-63000 Clermont-Ferrand, France

${ }^{3}$ AMAP, IRD, CIRAD, CNRS, INRA, Université Montpellier, Montpellier, France

${ }^{4}$ Department of Zoology \& Biodiversity Research Centre, University of British Columbia, 6270 University Blvd., Vancouver, British Columbia, V6T 1Z4, Canada.

${ }^{5}$ Ecolab, Laboratoire Ecologie Fonctionnelle et Environnement, CNRS, Université de Toulouse, 118 route de Narbonne, 31062 Toulouse, France

Corresponding author; e-mail: hector.hrp@gmail.com

\# Present address: Univ Rennes, CNRS, ECOBIO UMR 6553, F-35000, Rennes, France.

‡ Present address: Institut Pasteur, Laboratoire Biologie Moléculaire du Gène chez les Extremophiles. 25-28, rue du Docteur Roux, 75015 Paris, France.

HRP, CL, J-FC, BC, DSS, RC conceived and designed the experiment, HRP, GB, CL, J-FC, BC, RC performed the experiment. HRP, GB, DSS analyzed the data, HRP, DSS, RC wrote the manuscript, and all authors contributed critically to the drafts and gave final approval for publication. 


\section{Summary}

Future climate scenarios forecast a 10 to 50\% decline in rainfall in Eastern Amazonia. Altered precipitation patterns may change important ecosystem functions like decomposition through either changes in physical and chemical processes or shifts in the activity and/or composition of species. We experimentally manipulated hydroperiods (length of wet:dry cycles) in a tank bromeliad ecosystem to examine impacts on leaf litter decomposition. Gross loss of litter mass over 112 days was greatest in continuously submersed litter, lowest in continuously dry litter, and intermediate over a range of hydroperiods ranging from eight cycles of 7 wet:7 dry days to one cycle of 56 wet:56 dry days. The resilience of litter mass loss to hydroperiod length is due to a shift from biologically-assisted decomposition (mostly microbial) at short wet:dry hydroperiods to physicochemical release of dissolved organic matter at longer wet:dry hydroperiods. Biologically-assisted decomposition was maximized at wet:dry hydroperiods falling within the range of ambient conditions (12-22 consecutive dry days) but then declined under prolonged wet:dry hydroperiods (28 and 56 dry days. Fungal:bacterial ratios showed a similar pattern as biologically-assisted decomposition to hydroperiod length. Our results suggest that microbial communities confer functional resilience to altered hydroperiod in tank bromeliad ecosystems. We predict a substantial decrease in biological activity relevant to decomposition under climate scenarios that increase consecutive dry days by 1.6- to 3.2-fold in our study area, whereas decreased frequency of dry periods will tend to increase the physicochemical component of decomposition.

Keywords: Climate change, leaf-litter decomposition, resilience, dry:wet cycles, tankbromeliad ecosystem 


\section{Introduction}

Anthropogenic climate change will increase the frequency and intensity of extreme climatic events in many parts of the world (IPCC 2013). In neotropical regions, prolonged dry seasons related to more severe El Niño Southern Oscillation events (ENSO) have been recorded since the mid-70's (Collins 2005), while future scenarios forecast a further 10 to $50 \%$ decline in rainfall in the northern and eastern coasts of South America and in central Amazonia (IPCC 2013, Feng et al. 2013). Negative impacts of altered precipitation have been reported for the distribution, abundance and/or activity of a broad range of plants and animals (Grant et al. 2000; Gilbert et al. 2001; Itioka and Yamauti 2004; Allen et al. 2010; Dejean et al. 2011; Bonal et al. 2016), and may have consequences for the flow of energy and nutrients within ecosystems (Trzcinski et al. 2016). However, a number of biological mechanisms that operate at different levels of organization (e.g., ecological plasticity, compensatory responses among coexisting organisms, functional redundancy, metacommunity dynamics, etc.) can contribute to ecosystem resilience, that is, the stability of ecosystem functions over time despite fluctuations in environmental conditions (Gunderson 2000; Oliver et al. 2015).

Detrital decomposition is a key process in nutrient and carbon cycling on the local to global scale, supporting food webs in terrestrial and aquatic ecosystems. This biological breakdown of coarse organic matter fuels microbial and plant productivity, and returns $\mathrm{CO}_{2}$ to the atmosphere (Gessner et al. 1999). Once chemical-physical properties of detrital substrates are accounted for, both environmental conditions (e.g., temperature and/or hydrological regimes) and the composition and activity of decomposer communities interactively affect decomposition (Gessner et al. 2010). In particular, drought-induced stress is expected to impact decomposition either through lethal or sublethal effects on microbial and metazoan decomposers (Rees et al. 2006; Ledger et al. 2013; Trzcinski et al. 2016). Because any change 
in decomposition rates will alter the productivity and carbon budget of ecosystems, determining the extent to which biologically-assisted decomposition is resilient to changes in environmental regimes could improve our ability to predict the impact of climate change on ecosystems.Biologically-assisted decomposition depends on microbial and metazoan decomposers (Gessner et al. 1999, 2010), two groups of organisms that differ in their biology (e.g., growth rates) and ecology (e.g., sensitivity to drought) (Boyero et al. 2011; Shade et al. 2012). Therefore, functional resilience to altered hydrology may depend on how drought affects the abundance and relative contribution of microorganisms and metazoa in a system. Experiments conducted in temperate systems have shown that an increase in the duration of drought adversely affects leaf litter decomposition (Langhans and Tockner 2006) whereas an increase in drought frequency has either a moderate (Langhans and Tockner 2006; Foulquier et al. 2015) or positive impact on decomposition (Battle and Golladay 2001). Resilience to drought is inherent to ecosystems that are periodically subject to hydrological resetting (e.g., Mediterranean or arid-land freshwaters), where in situ resistance traits of species ensure rapid and repeated recovery of ecological functions after disturbance (Bogan et al. 2015). In addition to biological mechanisms underlying drought effects on decomposition, physicochemical processes due to litter emersion and/or dehydration (photodegradation, fractionation, etc) may dominate the overall decomposition process, so the frequency and duration of dry periods could affect the relative importance of biological-assisted and physicochemical litter breakdown (Andersen and Nelson 2006, Austin and Vivanco 2006). Little is known however of the extent to which microbial and/or faunal components of tropical food webs mediate ecosystem resilience to drought. Fungi and bacteria are probably the most influencial decomposers in neotropical ecosystems (Boyero et al. 2011), but they play different roles during the decomposition process (Strickland and Rousk 2010). Changes 
in fungal:bacterial dominance could thus affect decomposition rates, but we know little of hydrological thresholds beyond contemporary climate patterns that would trigger such changes in microorganism dominance. In soil microbial communities, fungi are less sensitive to changes in moisture than bacteria, making them more resilient to hydrological changes. Furthermore, higher fungal:bacterial ratios were associated to higher decomposition efficiency (Pascoal and Cassio 2004; Strickland and Rousk 2010; Foulquier et al., 2015; Malik et al. 2016). Changes in drought intensity and/or frequency could also adversely affect decomposition either through declines of invertebrate populations (Ledger et al. 2013), or through sublethal effects altering invertebrate per capita functions (Trzcinski et al. 2016). Hence, while models that link environmental change, community structure and ecosystem functions are needed to predict ecosystem resilience to drought, disentangling the contribution of microorganisms and invertebrates to litter decomposition across gradients of hydrological disturbance could improve our ability to predict the impact of environmental change on ecosystems, and, more importantly, tipping points for a particular ecosystem process.

Manipulating hydrology at the whole-ecosystem level with sufficient replication is often impractical. Experimental mesocosms can be replicated at will, with only space and/or budget limitations restriction, but are criticized for their lack of realism (Stewart et al. 2013). Tank bromeliads (Bromeliaceae) are increasingly used as model ecosystems to test ecological hypotheses (Srivastava et al. 2004) because they are small in size, can be exhaustively sampled, and contain multiple trophic levels and functional feeding groups. The water-filled rosettes of tank bromeliads form small, highly replicated freshwater systems. The interlocking leaves collect rainwater (up to 4-5 liters) and incoming detritus (mostly leaf litter) that support a microbial and faunal food web (Brouard et al. 2012). As in other freshwater systems, fungi, bacteria and invertebrate shredders break down the coarse detritus into fine particles, which 
are then further processed by invertebrate collectors and filterers, bacteria, and other heterotrophic microorganisms (i.e., protozoa, micrometazoa; Kitching 2009). Because their hydrology is sensitive to short and long-term fluctuations in precipitation (Zotz and Thomas 1999), tank bromeliads and their biota have been considered a suitable model to test the effects of a range of drought regimes on leaf litter decomposition in a neotropical environment (Trzcinski et al. 2016).

Neotropical ecosystems may undergo larger shifts in ecosystem functions than their temperate counterparts, because their species have narrower physiological tolerances for climatic variation (Tewksbury et al. 2008). However, the lack of empirical evidence on how drought affects community-mediated processes in neotropical ecosystems hinders our ability to predict how these ecosystems will respond to future changes, and more importantly, the extent to which ecosystem functions show resilience to altered hydrology. Our study was conducted in French Guiana which is part of the Guiana Shield in eastern Amazonia, where the intensification of the tropical Atlantic north-south sea surface temperature (SST) gradient is expected to enhance the duration and intensity of dry seasons (Malhi et al. 2008). In a field experiment conducted in tank bromeliads, we subjected leaf litter to a hydrological gradient of wet:dry hydroperiods ( 7 wet:7 dry to 56 wet: 56 dry days) over 112 days, and tested the subsequent effects on litter mass loss depending on the associated biota (microorganisms only vs. microorganisms and invertebrates). We analysed the responses of the gross (physicochemical + biological) and biologically-assisted decomposition to this gradient, and the extent to which decomposition shows resilience to recurrent drought. Specifically, we tested the following predictions: (i) assuming that climate history has shaped the functional response of current communities (Strickland et al. 2015), only drought intensities that exceed ambient ranges should trigger significant shifts in ecosystem processes, towards a reduction in 
mass loss rates; and (ii) assuming that microorganisms have the greatest influence on detrital decomposition in neotropical aquatic ecosystems (Boyero et al. 2011, 2015; Leroy et al. 2017), the effects of hydroperiod (frequency and intensity) on decomposition should be mostly mediated by drought-induced shifts in microbial community structure.

\section{Material and methods}

\section{Study area and bromeliad species}

We conducted our experiment in French Guiana, in a lowland rainforest located near the Petit-Saut hydroelectric dam, Sinnamary (latitude: $5^{\circ} 03^{\prime} 43^{\prime \prime} \mathrm{N}$; longitude: $53^{\circ} 02^{\prime} 46$ " $\mathrm{W}$; elevation a.s.1.: $80 \mathrm{~m}$ ). The maximum and minimum monthly temperature averages are $33.5^{\circ} \mathrm{C}$ and $20.5^{\circ} \mathrm{C}$ respectively. The climate is moist tropical, with $3000 \mathrm{~mm}$ of yearly precipitation. The dry season extends between September and November, and there is another shorter and more irregular dry period in March. The maximum number of consecutive days without rainfall in a dry season in our study area is $17 \pm 5.3$ (annual mean $\pm \mathrm{SD}$, based on daily rainfall records over the past ten years (Dejean et al. 2011; Dézerald et al. 2015).

The tank bromeliad Aechmea aquilega (Salib.) Griseb. commonly occurs in the study area. Its large size allows for placement of flow-through enclosures within the wells formed by leaf axils. We selected forty-five plants with similar vegetative traits (number of leaves, height, canopy width) and maximum water volume (measured as overflow of a known water volume using a graduate cylinder) for the experiment (mean length of longest leaf $93.9 \pm 22.9$ $\mathrm{cm}$, mean water volume of a leaf axil $113.8 \pm 69.4 \mathrm{ml})$. Each plant was potted and then randomly located within the experimental forest plot. We ensured that incident radiation (the available solar radiation received by a bromeliad) above individual plants was consistent 
(mean \pm SD: $30.6 \pm 7.1 \%$, calculations based on hemispherical photographs taken above each bromeliad and image processing in Gap Light Analyser software, as in Leroy et al. (2009)). The mean temperature inside plant wells was $24.4 \pm 0.6^{\circ} \mathrm{C}$, and was similar to the mean air temperature $\left(24.2 \pm 0.7^{\circ} \mathrm{C}\right.$, hourly records obtained with ibutton ${ }^{\circledR}$ dataloggers $)$.

Biological communities were homogenized six days prior to the experiment. The wells of each bromeliad were carefully sampled by pipetting out the contained water, detritus and aquatic organisms using $10-\mathrm{mL}$ micropipettes with the end trimmed to widen the aperture (Jocque et al. 2010). To maximize the sampling efficiency, the water was sucked in and out three times before extracting it. The samples were pooled in a large bucket, and the overall contents were then mixed and divided by the number of plants to equalize water volumes and biological communities.

\section{Leaf litter and flow-through enclosures}

We chose two species of trees for leaf litter, Goupia glabra Aubl. (Goupiaceae) and Platonia insignis Mart. (Clusiaceae), that are among the fastest species to decompose in soil environments in French Guiana (Coq et al. 2010; Hättenschwiler and Jørgensen 2010). Both tree species are very common in French Guiana, and their leaves are frequently found as litter in bromeliad tanks. We used nets to trap dead leaves as they fell from the tree canopy. All leaves were hydrated in filtered rainwater for $24 \mathrm{~h}$, and then cut into strips (see below), avoiding the central vein. Leaf strips were then oven dried at $60^{\circ} \mathrm{C}$ for $48 \mathrm{hrs}$, and weighted to the nearest $0.1 \mathrm{mg}$.

We constructed flow-through enclosures from Fischer® injection anchor sleeves, which form a rigid but perforated cylindrical plastic tube (diameter $=16 \mathrm{~mm}$, length $=85 \mathrm{~mm}$, mesh size $=1 \mathrm{~mm})$. Half of the enclosures were modified by drilling additional holes $(\sim 4 \mathrm{~mm}$ 
diameter, Fig. 1) to allow invertebrate colonization and movement (hereafter, "coarse mesh"). The other half of the enclosures were covered with $80 \mu \mathrm{m}$ Nitex ${ }^{\circledR}$ mesh (Fig. 1) to allow for water flow but prevent invertebrates access (hereafter, "fine mesh"). Each flow-through enclosure received six leaf strips, i.e. two $1 \times 4 \mathrm{~cm}$ and one $1 \times 5 \mathrm{~cm}$ strips of each litter species (Fig.1). The dry mass of a $1 \mathrm{x} 4 \mathrm{~cm}$ strip was $0.0715 \pm 0.0119 \mathrm{~g}$ in G. glabra, and $0.0769 \pm$ $0.0126 \mathrm{~g}$ in $P$. insignis (mean $\pm \mathrm{SD}$ values). The total litter biomass enclosed in the mesh tubes was similar to the natural biomass of dead leaves in bromeliads at our site (Trzcinski et al. 2016). The $1 \times 5 \mathrm{~cm}$ strips were used for DNA extraction to estimate the numbers of fungal and bacterial gene copies directly associated with the leaf strips (see below). The $1 \mathrm{x} 4 \mathrm{~cm}$ strips were used to estimate leaf litter mass loss. We also extracted fungal and bacterial DNA from three freshly fallen leaves from each species, to obtain reference values for fungal and bacterial gene copies that could be compared to those numbers observed in our various treatments.

\section{Wet:dry hydroperiod treatments and set up}

Based on records from the Petit Saut weather station ( $8 \mathrm{~km}$ away from our field site), the number of consecutive days without rainfall in a dry season over the past 10 years ranged from 3 to 28 days. We therefore created three treatments with a number of dry days falling within this range, and an "extreme" treatment doubling the maximum number of dry days to 56 (to force the system). Our experiment thus included four hydroperiod treatments (Fig. 1) that all had a total of 56 wet days and 56 dry days but differed in the distribution of these days into consecutive wet: consecutive dry day hydroperiods (eight cycles of 7 wet:7 dry days, four cycles of 14 wet:14 dry days, two cycles of 28 wet: 28 dry days, one cycle of 56 wet:56 dry days). Wet:dry hydroperiod treatments are denoted by the number of cycles subscripted by the number of consecutive days in a wet or dry phase (i.e., $8_{7}=$ eight cycles of 7 wet: 7 dry days). 
The four hydroperiod treatments were crossed with a "decomposer" factor which included two levels: fine mesh enclosures (microorganisms only) and coarse mesh enclosures (microorganisms + invertebrates). Each combination was replicated 18 times. We randomly assigned a given wet:dry hydroperiod treatment to a total of 36 plants. Each plant received four enclosures: one coarse- and one fine-mesh enclosures starting the experiment with the wet phase of the cycle, and another two enclosures, one of each mesh size, starting with the dry phase of the cycle (see Fig. 1). We used an additional set of 9 plants for control. Each of these 9 plant received 2 pairs of coarse- and fine-mesh enclosures containing leaf litter strips: one couple immersed for the 112 days of the experiment served as "wet control" (Fig. 1), the other couple kept in dry conditions under a rainshelter for 112 days served as "drought control" (Fig. 1). In all bromeliads, both the coarse- and fine-mesh enclosures were placed together in a large well, avoiding the central reservoir (delimited by growing young leaves) and basal senescent wells. Enclosures experiencing the wet phase of their cycle were immersed in bromeliad water. Enclosures experiencing the dry phase of their cycle were suspended just above the well, exposed to air under a small rain shelter to prevent rewetting. Shelters were made by cutting a PET $1.5 \mathrm{~L}$ bottle of mineral water, and by using the upper part of the bottle tied to a wooden pole placed nearby the plant (see Fig. 1). Dry:wet hydroperiods were simulated by periodically raising enclosures above or lowering enclosures into the water as appropriate. This technique builds on earlier studies conducted in temperate rivers, where leaf packs in enclosures with different mesh sizes were transferred manually from aquatic to terrestrial environments to establish effects of hydroperiods and organisms on decomposition (Langhans and Tockner 2006; Bruder et al. 2011). We maintained a constant water level in all wells throughout the experiment.

\section{Biological variables}


At the end of the field experiment, all enclosures were collected and kept in a cooler for transportation. Invertebrates were exhaustively sampled in all bromeliads by repeated pipetting, before and after rinsing the wells with diluted vinegar. Samples were preserved in $70 \%$ ethanol (final concentration) in the field. Invertebrates found in the coarse mesh enclosures were sorted in the laboratory after careful inspection of the surface of each leaf strip. All invertebrates were identified to species or morphospecies, counted and categorized by functional feeding groups sensu Merritt and Cummins (1996). The 1x4cm leaf strips were dried at $60^{\circ} \mathrm{C}$ for $48 \mathrm{hrs}$ and weighted to the near $0.1 \mathrm{mg}$ to assess dry mass loss. The $1 \mathrm{x} 5 \mathrm{~cm}$ leaf strips were frozen prior to qPCR quantification of fungal and bacterial gene copy numbers, as described in the Appendix S1.

\section{Dissolved organic matter (DOM) release and leaf mass decay}

In order to evaluate the contribution of biologically-assisted decomposition to leaf mass loss, we assessed the contribution of pure physicochemical processes to litter mass loss in the laboratory (essentially DOM release due to leaching, and potentially physical fractionation due to desiccation and rewetting). We incubated 30 coarse-mesh enclosures (identical to those used in the field) consisting of 6 replicates of each of 5 treatments $\left(1_{56}, 2_{28}, 4_{14}, 8_{7}\right.$ and a wet control, as defined earlier), in a $2 \mathrm{~L}$ container. The container was filled with distilled water containing streptomycin and ampicillin antibiotics at a concentration of $50 \mathrm{mgL}^{-1}$ each, following the protocol and concentrations used by (Mille-Lindblom and Tranvik 2003) to prevent the development of fungi and bacteria. Each enclosure contained two $1 \mathrm{x} 4 \mathrm{~cm}$ leaf strips of each litter species, and the experiment lasted 112 days. The antibiotics were renewed every 10 days, reaching a final concentration of $0.5 \mathrm{~g} . \mathrm{L}^{-1}$. At the end of the experiment, leaf strips were dried as described above and weighed to evaluate mass loss due to pure physicochemical effects. 


\section{Data analysis}

Differences in final invertebrate communities among experimental plants were tested with a permutation MANOVA test (Anderson 2001), using Bray-Curtis dissimilarities on $\log (\mathrm{x}+1)$-transformed invertebrate abundances.

Mass loss rate of leaf litter was used as a dependent variable to assess how leaf decomposition responded to the gradient of dry:wet cycles. We ran separate analyses for observed mass loss rate (gross decomposition) and mass loss rate corrected for DOM release (biologically-assisted decomposition). The ratio between numbers of fungal and bacterial gene copies was used as a dependent variable to test the effect of treatments on the fungus:bacteria ratio. Prior to analysis, we transformed proportions with a logit function to achieve homoscedasticity in residuals. Separate mixed effect models were ran for each leaf litter species, testing hydroperiod (4 wet:dry cycles and two controls) and mesh size (coarse or fine mesh) as fixed effects. Plant identity (individual bromeliads used for the experiment, 45 levels) and the condition of the initial phase (dry or wet) nested within plant identity were included as random effects in the models. We also explored the effect of the following covariates: maximum water volume (WV, ml), percentage incident radiation (IR), invertebrate taxonomic richness (Richness), total density of shredder-scrapers (Density_Shre ind. $\mathrm{ml}^{-1}$ ), and density of each shredder-scraper taxon occurring inside plant wells (Cyphon sp. (Density_Cyph), Trentepohlia (Density_Trent) and Telmatoscopus sp. (Density_Telma). When one factor was significant we used Tukey's HSD test to examine pairwise differences between levels of the given factor. Additionally, to specifically test our prediction that drought intensities exceeding ambient ranges should negatively impact mass loss rates, we used a priori Helmert's orthogonal contrasts in linear models analyzing gross decomposition data. Contrast 1 compared the mean of the dry control to the mean of all other levels of 
hydroperiod factor. Contrast 2 compared the mean of the wet control to the mean of all experimental levels $\left(1_{56}, 2_{28}, 4_{14}, 8_{7}\right)$. Contrast 3 tested the effect of dry:wet cycles $>7$ days, comparing the mean of the $8_{7}$ treatment to the mean of the three other hydroperiods $\left(4_{14}\right.$, $228,156)$. Contrast 4 tested the effect of dry:wet cycles $>14$ days, by comparing the mean of the $4_{14}$ treatment to the mean of the $2_{28}$ and $1_{56}$ treatments. Contrast 5 tested the effect of dry:wet cycles $>28$ days, comparing the mean of the $2_{28}$ treatment with the mean of treatment $1_{56}$. Model fit was evaluated graphically by exploring residuals patterns. In order to evaluate the effect of drought treatments on just biologically-assisted decomposition, we applied the same procedure to leaf litter mass losses corrected for mean physicochemical loss of litter mass for that specific hydroperiod treatment.

We used univariate ANOVAs for the DOM release experiment, with the loss of litter dry mass as the dependent variable. We ran independent ANOVA tests for each leaf litter species. Data were logit transformed and drought treatment was the independent variable with 5 levels (cycles days): $156,2_{28}, 4_{14}, 8_{7}$ and wet control. Residuals patterns were explored graphically to assess departure from assumptions of the analysis.

All statistical analyses were performed with R software (R Core Team 2014) and the following packages: car (Fox and Weisberg 2011), nlme ver. 3.1-118 (Pinheiro et al. 2014) and vegan ver. 2.2-1 (Oksanen et al. 2015).

\section{Results}

Leaf litter mass loss response to altered hydroperiod 
Intermediate mass losses were recorded in intermittent water availability treatments (i.e. wet:dry hydroperiod treatments; Fig. 2A, 2B). According to pair-wise comparisons, regardless of litter species, mass loss did not differ significantly among the four wet:dry hydroperiod treatments $\left(1_{56}, 2_{28}, 4_{14}\right.$ and 87 ; Table 1), ranging from 20 to $21.7 \%$ in G. glabra and from 15.1 to $18.5 \%$ in P. insignis in these treatments. On the other hand, only for $G$. glabra, Helmert's constrasts pointed out a significant higher mass loss rate for 87 treatment compared with the rest of experimental hydroperiod treatments $\left(1_{56}, 2_{28}, 4_{14}\right.$; Table 2$)$. Mass loss of leaf litter was the lowest in drought control and the highest in wet controls. In $G$. glabra, the drought control had substantially lower (9.8\%) mass loss and the wet control had higher (29.7\%) mass loss than the wet:dry hydroperiod treatments (Fig. 2A). Similarly, in $P$. insignis, the drought control had significantly lower (6.6\%) mass loss than the wet:dry hydroperiod treatments, whereas the wet control lost significantly more mass (18.4\%) than the 156 treatment (15.1\%) and the drought control (Fig. 2B).

Under antibiotic incubation in the laboratory, we recorded 4-12\% mass loss over 112 days. The rate of DOM release depended on the length of the hydroperiod (G. glabra $\mathrm{F}=4.33$, $\mathrm{df}=4, \mathrm{p}=0.008$ and $P$. insignis $\mathrm{F}=20.87, \mathrm{df}=4, \mathrm{p}<0.001)$. We estimate that such physicochemical mass loss from litter represented $20-60 \%$ of the gross mass loss recorded in our field experiment (Fig 2A, 2B). At longer hydroperiods (156 and 228 , we estimated that DOM release accounted for $50-52 \%$ and $60-61 \%$ of the dry mass losses in G. glabra and $P$. insignis, respectively. At shorter hydroperiods ( $4_{14}$ and 87$), 32-34 \%$ and $22 \%$ of the mass loss was due to DOM release in G. glabra and P. insignis, respectively. Only in P. insignis, there was additionally a significant decrease in mass loss due to DOM release between the wet control and the $1_{56}$ and $2_{28}$ treatments, and between each of the two former groups and the $4_{14}$ and 87 treatments. Therefore, when gross leaf litter mass losses were corrected for treatment- 
specific DOM release (Fig 2C, 2D), biologically-assisted decomposition was significantly higher at shorter cycles $\left(4_{14}\right.$ and $\left.8_{7}\right)$ than at longer dry periods ( $1_{56}$ and $\left.2_{28}\right)$. Interestingly, the litter species differed in how continuous immersion affected biological decomposition: in $G$. glabra, wet control litter had the highest rates of biologically-assisted decomposition whereas in P. insignis, wet control litter had some of the lowest rates of biologically-assisted decomposition (Table 1, Fig 2C, 2D).

\section{Shifts in fungal:bacterial dominance}

Absolute bacterial and fungal abundances (proxied by numbers of gene copies) were highest when invertebrates had access to leaf litter that underwent at least one dry period $\left(2_{28}\right.$, $4_{14}, 8_{7}$, Fig 3A, 3B), and when invertebrates were absent in litter that was permanently immersed (156 and wet control). Fungal:bacterial ratios on the surface of the leaf strips were significantly lower in coarse mesh enclosures (microorganisms + invertebrates) than in fine mesh enclosures (microorganisms only) for G. glabra and P. insignis $(+2.9 \%$ and $+5 \%$ on average, respectively, Table 2, Fig 3C, 3D), revealing that invertebrate presence or activity decreased the dominance of fungi over bacteria. More frequent drying tended to result in higher fungal:bacterial ratios for both litter species, significantly for $P$. insignis and marginally ( $\mathrm{p}=0.06$ ) in G. glabra (Table 2). Regardless of the leaf litter species, the interaction between wet:dry hydroperiod treatment and mesh size had no significant effect on litter mass loss and fungal:bacterial ratio (Table 2). Other covariates were not significant and were thus removed from the analyses (results not shown). 
At the end of the experiment, invertebrate communities did not differ between bromeliads used for the six manipulation types (dry control, wet control, and each of the four drought treatments; MANOVA PseudoF $=1.36, \mathrm{df}=4, \mathrm{p}=0.1$ ). We sorted a total number of 10,301 invertebrates including: oligochaetes (Aulophorus superterrenus, $54.8 \%$ of the total abundance), dipterans (Culex sp. 21.1\%, Chironomini 5\% and Tanyponidae 3.5\%), ostracods (Elpidium bromeliarium 7\%) and odonates (unidentified Coenagrionidae, 3\%). The dominant functional feeding groups were gathering-collectors $(>90 \%)$ and predators $(6.6 \%)$. Shredders (Trentepohlia sp. and Telmatoscopus sp. dipterans) and scrapers (Cyphon sp. coleopteran) only accounted for $1.3 \%$ of the total abundance.

Biologically-assisted decomposition in drought treatments and controls was essentially due to microbial activities. In G. glabra leaves, the increase of decomposition rate due to invertebrates was $1.5 \%$ only (Table 1, Fig $2 \mathrm{~A}$ ). For P. insignis, there was no difference in leaf litter mass loss between fine mesh and coarse mesh enclosures. Gross mass loss correlated significantly and positively with densities of Trentepohlia sp. (shredder) and Cyphon sp. (scraper) for both litter species, whereas biologically-assisted mass loss correlated significantly with densities of Trentepohlia sp. and Cyphon sp. for G.glabra and only with Cyphon sp. for P. insignis (Table 1).

\section{Discussion}

Whilst water availability and precipitation are the main factors controlling decomposition in tropical forests in general (Powers et al. 2009), future climate scenarios predict an increase in the frequency of dry episodes and the intensity of dry seasons in eastern Amazonia, including the Guiana Shield (IPCC, 2013). In addition to direct effects on species' metabolism and activity, environmental change causing significant shifts in community 
functional structure and resilience capability could precipitate abrupt changes in ecosystem functions (MacDougall et al. 2013). In our experiment, we did not reach a sharp decline in decomposition, although we simulated recurrent 7 to 56 days-long dry periods, i.e. up to three-times the maximum number of consecutive days without rainfall under ambient climate (17 days on average). Even if bromeliad tanks do not dry out immediately in the absence of rainfall, water level decreases quickly over consecutive days without rain, progressively exposing the leaf litter to the air from its upper to its lower parts. Our results suggest that cooccurring physicochemical and biological decomposition processes have opposite responses to drought, likely hindering our ability to detect hydrological thresholds that trigger significant alterations in functions sustained by biological communities. Within the range of simulated hydroperiods, microbial decomposition was maximized at short hydroperiods falling within the range of current ambient conditions (7-14 dry days), but then declined significantly under prolonged dry periods (28 and 56 days), together with a significant decrease in fungal:bacterial ratios. If climate has shaped the current functional responses of communities to hydrological changes, our result suggest that an ecosystem process such as biological decomposition of leaf litter would currently be close to its 'functional optimum' in the study area (Wallestein and Hall 2012).

The resilience of ecosystem functions to altered hydrology theoretically relies on the capability of influential community components to withstand perturbations (Oliver et al. 2015). Here, we manipulated litter and the microorganisms and invertebrates that colonize leaf packs to break down the dead leaves, and our results point to a major role for microorganisms in the decomposition process. Invertebrate shredders are scarce in most tropical aquatic ecosystems (Boyero et al. 2011), and this is particularly true of freshwaters of French Guiana in general (Dedieu et al. 2016). Compared to other Neotropical regions, 
shredder density and biomass is particularly low in tank bromeliads of French Guiana (Brouard et al. 2012), so whatever their resistance to altered hydroperiod they likely play a minor role in ecosystem resilience (Leroy et al. 2017). We manipulated only the hydrated state of the flow-through enclosures, by raising or lowering them. Therefore, the aquatic bacteria, fungi and invertebrates that colonized the leaf packs had to resist and recover (or eventually dried out). It is however likely that, under natural drought events, terrestrial macroinvertebrates would be able to colonize the leaf packs and continue decomposition in the absence of water. That said, the low direct contribution of aquatic shredders and scrapers to decomposition suggest that the main effect of invertebrates is through indirect effects on microorganisms. The numbers of gene copies for bacteria and fungi were higher in coarse mesh enclosures for the treatments alternating wet and dry phases. Invertebrates also reduced the proportion of fungi over bacteria in both litter species, a pattern consistent with increased litter palatability (Wymore et al. 2013). It may be that invertebrates, by fragmenting larger detrital particles (Gessner et al. 1999), enhances bacterial colonization and therefore litter mass loss. This indirect effect was however only significant for G. glabra, the most palatable litter.

Microbial communities, which had the greatest biological influence on decomposition adapt rapidly to fluctuating water availability (Bouskill et al. 2013). Microbial communities are notably highly diversified, so functional redundancy could buffer adverse effects of environmental changes on ecological processes (Allison and Martiny 2008). Fungal assemblages respond rapidly to rewetting (Fierer et al. 2003), and bacteria buffer hydric stress by exuding polysaccharides to form biofilms. Furthermore, dry periods can increase resistance in microbial communities by filtering out drought-sensitive species and increasing the prevalence of the drought-resistant ones, so that subsequent droughts result in functional 
response close to that of non-perturbed communities (Bouskill et al. 2013). For instance, an increase in the production of hydrolytic enzymes responsible for the breakdown of complex organic C compounds (thus enhancing decomposition) was observed by Bouskill et al. (2016) in samples subjected to repeated drought perturbation. Dry-wet cycles increase litter decomposition through cell wall damage, but also through hydrolysis of cellulose and related compounds (Taylor and Parkinso 1988; Alarcon-Gutierrez et al. 2010). Extracellular enzymatic activity is related to water content and drying-rewetting cycles increase the leaf litter capacity to retain water, thus increasing enzymatic activity. Drying-rewetting cycles enhance the lysis of dead microbial cells and the subsequent release of intra-cellular content make leaf tissues more digestible for decomposing microorganism penetration (AlarconGutierrez et al. 2010; Mora-Gómez et al. 2018).

Fungi and bacteria however differ in their sensitivity to changes in hydroperiod. In our experiment, hydroperiod affected microbial community structure in terms of fungal:bacterial dominance. Short wet:dry hydroperiods $\left(8_{7}\right.$ and $\left.4_{14}\right)$ were characterized by higher fungi:bacteria ratios, denoting decreased bacterial growth while fungal growth remained unaffected or was boosted. These results are consistent with experiments on soil microbial communities for which drying-rewetting cycles lead to an increase in the fungal:bacterial ratio (Bapiri et al. 2010). The higher fungal activity (hence biologicallyassisted decomposition) at shorter dry:wet cycles is probably related to the residual moisture in leaf packs allowing microorganisms to survive short dry periods and the facilitation due to the lysis of leaf litter tissue during repeated drying-rewetting. Our results suggest that the effects of hydroperiod on the biological fraction of the decomposition process are mediated by shifts in microbial community structure (Pesce et al. 2016). 
Decomposition as a whole also has a physicochemical component, and its relative contribution (versus biologically-assisted decomposition) depended on hydroperiod. Interestingly, more frequent droughts appeared to limit DOM release, thereby masking the effects of enhanced fungal:bacterial ratio in the gross decomposition. We acknowledge that we did not measure bacterial nor fungi biomass in the antibiotic treatments conducted in the laboratory. Still, mass loss for the same wet:dry treatment differred between fine mesh enclosures in the field (microorganisms present) and laboratory experiment (microorganisms supposedly inhibited) (Fig. 2), suggesting efficient inhibition effect of antibiotics in the laboratory experiment. It is worth noting that in P. insignis, biologically-assisted decomposition (Fig. 2D) was even higher in the 87 and $4_{14}$ drought treatments than in the wet and drought controls. Finally, decomposition rates also depend on leaf chemistry. Detailed studies of the nutrient and tannin content of G. glabra and P. insignis in French Guiana can be found in Coq et al. (2010), and Hättenschwiler and Jorgensen (2010). With the expection of phosphorus (higher P concentrations in G. glabra), the leaves of G. glabra and P. insignis only show slight differences in their chemistry. Assuming that nutrient concentrations are important determinants of leaf litter decomposition (Makkonen et al. 2012; García-Palacios et al. 2016), higher P concentations in G. glabra could explain the slightly higher mass loss rates for this species (Fig. 1).

In conclusion, the results of our manipulative experiment predict a meaningful decrease in biological activity relevant to the decomposition processes under climate scenarios that would increase current numbers of consecutive dry days, whereas decreased frequency of dry periods will tend to increase the physicochemical component of decomposition. Apparent responses likely hide evidence for hydrological thresholds associated with the near-optimum functional efficiency of communities, indicating that the 
mechanisms that underpin interactions between these biological and abiotic responses deserve further attention. Uncertainties however remain as regards community and ecosystem function resilience, because we did not further analyze shifts at microbial community composition in terms of taxonomic and functional trait diversity. Moreover, variation of leaf litter traits in relation to regional climates might influence the magnitude of biological effect on detrital mass loss (Hättenschwiler and Jørgensen 2010). It is also likely that (bio)geographic variations in invertebrate community structure (e.g., presence or absence of large-bodied invertebrate predators, density of shredders), in addition to variations of leaf litter quality will modulate functional resilience to drought through top-down or bottom-up effects on decomposers (Trzcinski et al. 2016). Further experimental study would therefore be needed to determine the extent to which species turnover and leaf traits determine hydrological thresholds relative to local, ambient climate.

\section{Acknowledgements}

We thank the members of the Laboratoire Environnement de Petit Saut (HYDRECO) for technical support and the use of their facilities, and A. Compin (CNRS, UMR ECOLAB, Toulouse), M. Fichaux and F. Petitclerc (CNRS, UMR ECOFOG, Kourou) for field assistance. Financial support was provided by the Agence Nationale de la Recherche throughout the Rainwebs project (grant ANR-12-BSV7-0022-01), an "Investissement d'Avenir" grant (Labex CEBA, ref. ANR-10-LABX-25-01), and a CNRS grant to the Groupement De Recherche International "Environmental Forcing on Freshwater biodiversity and ecosystem functioning" (GDRI EFF). We thank Dr. Kneitel and two anonymous reviewers for constructive criticism on an earlier version of this paper. 


\section{Literature cited:}

Alarcon-Gutierrez E, Floch C, Ziarelli F, et al (2010) Drying-rewetting cycles and gammairradiation effects on enzyme activities of distinct layers from a Quercus ilex L. litter. Soil Biol Biochem 42:283-290. doi: 10.1016/j.soilbio.2009.11.005

Allen CD, Macalady AK, Chenchouni H, et al (2010) A global overview of drought and heatinduced tree mortality reveals emerging climate change risks for forests. For Ecol Manag 259:660-684. doi: 10.1016/j.foreco.2009.09.001

Allison SD, Martiny JBH (2008) Resistance, resilience, and redundancy in microbial communities. Proc Natl Acad Sci 105:11512-11519. doi: 10.1073/pnas.0801925105

Anderson MJ (2001) A new method for non-parametric multivariate analysis of variance. Austral Ecol 26:32-46

Bapiri A, Bååth E, Rousk J (2010) Drying-Rewetting Cycles Affect Fungal and Bacterial Growth Differently in an Arable Soil. Microb Ecol 60:419-428. doi: 10.1007/s00248-0109723-5

Battle JM, Golladay SW (2001) Hydroperiod Influence on Breakdown of Leaf Litter in Cypress-gum Wetlands. Am Midl Nat 146:128-145. doi: 10.1674/00030031(2001)146[0128:HIOBOL]2.0.CO;2

Bogan MT, Boersma KS, Lytle DA (2015) Resistance and resilience of invertebrate communities to seasonal and supraseasonal drought in arid-land headwater streams. Freshw Biol 60:2547-2558. doi: 10.1111/fwb.12522

Bonal D, Burban B, Stahl C, et al (2016) The response of tropical rainforests to droughtlessons from recent research and future prospects. Ann For Sci 73:27-44. doi: 
$10.1007 / \mathrm{s} 13595-015-0522-5$

Bouskill NJ, Lim HC, Borglin S, et al (2013) Pre-exposure to drought increases the resistance of tropical forest soil bacterial communities to extended drought. ISME J 7:384-394. doi: 10.1038/ismej.2012.113

Bouskill NJ, Wood TE, Baran R, et al (2016) Belowground Response to Drought in a Tropical Forest Soil. II. Change in Microbial Function Impacts Carbon Composition. Terr Microbiol 323. doi: 10.3389/fmicb.2016.00323

Boyero L, Pearson RG, Dudgeon D, et al (2011) Global distribution of a key trophic guild contrasts with common latitudinal diversity patterns. Ecology 92:1839-1848. doi: $10.1890 / 10-2244.1$

Boyero L, Pearson RG, Gessner MO, et al (2015) Leaf-litter breakdown in tropical streams: is variability the norm? Freshw Sci 34:759-769. doi: 10.1086/681093

Brouard O, Céréghino R, Corbara B, et al (2012) Understorey environments influence functional diversity in tank-bromeliad ecosystems. Freshw Biol 57:815-823. doi: 10.1111/j.1365-2427.2012.02749.x

Bruder A, Chauvet E, Gessner MO. (2011) Litter diversity, fungal decomposers and litter decomposition under simulated stream intermittency. Funct Ecol 25: 1269-1277. doi: 10.1111/j.1365-2435.2011.01903.x

Coq S, Souquet J-M, Meudec E, et al (2010) Interspecific variation in leaf litter tannins drives decomposition in a tropical rain forest of French Guiana. Ecology 91:2080-2091. doi: $10.1890 / 09-1076.1$ 
Dedieu N, Clavier S, Vigouroux R, et al (2016) A Multimetric Macroinvertebrate Index for the Implementation of the European Water Framework Directive in French Guiana, East Amazonia. River Res Appl 32:501-515. doi: 10.1002/rra.2874

Dejean A, Céréghino R, Carpenter JM, et al (2011) Climate Change Impact on Neotropical Social Wasps. PLOS ONE 6:e27004. doi: 10.1371/journal.pone.0027004

Dézerald O, Céréghino R, Corbara B, et al (2015) Functional trait responses of aquatic macroinvertebrates to simulated drought in a Neotropical bromeliad ecosystem. Freshw Biol 60:1917-1929. doi: 10.1111/fwb.12621

Feng X, Porporato A, Rodriguez-Iturbe I (2013) Changes in rainfall seasonality in the tropics. Nat Clim Change 3:811-815. doi: 10.1038/nclimate1907

Fierer N, Schimel JP, Holden PA (2003) Influence of drying-rewetting frequency on soil bacterial community structure. Microb Ecol 45:63-71. doi: 10.1007/s00248-002-1007-2

Foulquier A, Artigas J, Pesce S, Datry T (2015) Drying responses of microbial litter decomposition and associated fungal and bacterial communities are not affected by emersion frequency. Freshw Sci 34:1233-1244. doi: 10.1086/682060

Fox J, Weisberg S (2011) An R companion to applied regression, 2nd edition. Thousand Oaks CA, Sage.

García-Palacios P, McKie BG, Handa IT, et al (2016) The importance of litter traits and decomposers for litter decomposition: a comparison of aquatic and terrestrial ecosystems within and across biomes. Funct Ecol 30:819-829. doi: 10.1111/1365-2435.12589

Gessner MO, Chauvet E, Dobson M (1999) A Perspective on Leaf Litter Breakdown in 
Streams. Oikos 85:377-384. doi: 10.2307/3546505

Gessner MO, Swan CM, Dang CK, et al (2010) Diversity meets decomposition. Trends Ecol Evol 25:372-380. doi: 10.1016/j.tree.2010.01.010

Gilbert GS, Harms KE, Hamill DN, Hubbell SP (2001) Effects of seedling size, El Niño drought, seedling density, and distance to nearest conspecific adult on 6-year survival of Ocotea whitei seedlings in Panamá. Oecologia 127:509-516. doi: 10.1007/s004420000616

Grant PR, Grant BR, Keller LF, Petren K (2000) Effects of El Niño events on Darwin's finch productivity. Ecology 81:2442-

2457.doi:10.1890/00129658(2000)081[2442:EOENOE]2.0.CO;2

Gunderson LH (2000) Ecological Resilience-In Theory and Application. Annu Rev Ecol Syst 31:425-439. doi: 10.1146/annurev.ecolsys.31.1.425

Hättenschwiler S, Jørgensen HB (2010) Carbon quality rather than stoichiometry controls litter decomposition in a tropical rain forest. J Ecol 98:754-763. doi: 10.1111/j.13652745.2010.01671.x

Itioka T, Yamauti M (2004) Severe drought, leafing phenology, leaf damage and lepidopteran abundance in the canopy of a Bornean aseasonal tropical rain forest. J Trop Ecol 20:479-482. doi: $10.1017 / \mathrm{S} 0266467404001658$

Jocque M, Kernahan A, Nobes A, et al (2010) How effective are non-destructive sampling methods to assess aquatic invertebrate diversity in bromeliads? Hydrobiologia 649:293-300. doi: 10.1007/s10750-010-0272-1

Langhans SD, Tockner K (2006) The role of timing, duration, and frequency of inundation in 
controlling leaf litter decomposition in a river-floodplain ecosystem (Tagliamento, northeastern Italy). Oecologia 147:501-509. doi: 10.1007/s00442-005-0282-2

Ledger ME, Brown LE, Edwards FK, et al (2013) Drought alters the structure and functioning of complex food webs. Nat Clim Change 3:223-227. doi: 10.1038/nclimate1684

Ledger ME, Harris RML, Armitage PD, Milner AM (2012) Climate Change Impacts on Community Resilience. In: Advances in Ecological Research. Elsevier, pp 211-258

Leroy C, Corbara B, Dejean A, Céréghino R (2009) Ants mediate foliar structure and nitrogen acquisition in a tank-bromeliad. New Phytol 183:1124-1133. doi: 10.1111/j.14698137.2009.02891.x

Leroy C, Corbara B, Dézerald O, Trzcinski MK, Carrias JF, Dejean A, Céréghino R (2017) What drives detrital decomposition in neotropical tank bromeliads? Hydrobiologia 802: 8595. /doi.org/10.1007/s10750-017-3242-z

MacDougall AS, McCann KS, Gellner G, Turkington R (2013) Diversity loss with persistent human disturbance increases vulnerability to ecosystem collapse. Nature 494:86-89. doi: 10.1038/nature11869

Makkonen M, Berg MP, Handa IT, et al (2012) Highly consistent effects of plant litter identity and functional traits on decomposition across a latitudinal gradient. Ecol Lett 15:1033-1041. doi: 10.1111/j.1461-0248.2012.01826.x

Malhi Y, Roberts JT, Betts RA, et al (2008) Climate change, deforestation, and the fate of the Amazon. Science 319:169-172. doi: 10.1126/science.1146961

Malik AA, Chowdhury S, Schlager V, et al (2016) Soil fungal:bacterial ratios are linked to 
altered carbon cycling. Front Microbiol 7:. doi: 10.3389/fmicb.2016.01247

Mille-Lindblom C, Tranvik LJ (2003) Antagonism between bacteria and fungi on decomposing aquatic plant litter. Microb Ecol 45:173-182. doi: 10.1007/s00248-002-2030-z

Mora-Gómez J, Duarte S, Cássio F, et al (2018) Microbial decomposition is highly sensitive to leaf litter emersion in a permanent temperate stream. Sci Total Environ 621:486-496. doi: 10.1016/j.scitotenv.2017.11.055

Oliver TH, Heard MS, Isaac NJB, et al (2015) Biodiversity and resilience of ecosystem functions. Trends Ecol Evol 30:673-684. doi: 10.1016/j.tree.2015.08.009

Oksanen J, Blanchet FG, Kindt R, et al (2015) Vegan: Community ecology package. R 530 package version 2.2-1.531

Pascoal C., Cassio F (2004) Contribution of fungi and bacteria to leaf litter decomposition in a polluted river Appl. Environ. Microbiol. 70:5266-5273. doi: 10.1128/AEM.70.9.52665273.2004

Pesce S, Zoghlami O, Margoum C, et al (2016) Combined effects of drought and the fungicide tebuconazole on aquatic leaf litter decomposition. Aquat Toxicol 173:120-131. doi: 10.1016/j.aquatox.2016.01.012

Pinheiro J, Bates D, DebRoy S, Sarkan D, R Core Team (2014) Nlme: linear and nonlinear mixed effects models. R package version 3.1-118.

Powers JS, Montgomery RA, Adair EC, et al (2009) Decomposition in tropical forests: a pantropical study of the effects of litter type, litter placement and mesofaunal exclusion across a precipitation gradient. J Ecol 97:801-811. doi: 10.1111/j.1365-2745.2009.01515.x 
R Core Team (2014) A language and environment for statistical computing. R Foundation for Statistical Computing. Vienna, Austria.541

Rees GN, Watson GO, Baldwin DS, Mitchell AM (2006) Variability in sediment microbial communities in a semipermanent stream: impact of drought. J North Am Benthol Soc 25:370378. doi: 10.1899/0887-3593(2006)25[370:VISMCI]2.0.CO;2

Roger L. Kitching (2009) Food Webs and Container Habitats: The Natural History and Ecology of Phytotelmata. Cambridge University Press

Shade A, Peter H, Allison SD, et al (2012) Fundamentals of microbial community resistance and resilience. Front Microbiol 3:417. doi: 10.3389/fmicb.2012.00417

Srivastava DS, Kolasa J, Bengtsson J, et al (2004) Are natural microcosms useful model systems for ecology? Trends Ecol Evol 19:379-384. doi: 10.1016/j.tree.2004.04.010

Stewart RIA, Dossena M, Bohan DA, et al (2013) Chapter Two - Mesocosm experiments as a tool for ecological climate change research. In: O'Gorman GW and EJ (ed) Advances in Ecological Research. Academic Press, pp 71-181

Strickland MS, Keiser AD, Bradford MA (2015) Climate history shapes contemporary leaf litter decomposition. Biogeochemistry 122:165-174. doi: 10.1007/s10533-014-0065-0

Strickland MS, Rousk J (2010) Considering fungal:bacterial dominance in soils - Methods, controls, and ecosystem implications. Soil Biol Biochem 42:1385-1395. doi:

10.1016/j.soilbio.2010.05.007

Taylor BR, Parkinso D (1988) Does repeated wetting and drying accelerate decay of leaf litter? Soil Biol Biochem 20:647-656. doi: 10.1016/0038-0717(88)90149-6 
Tewksbury JJ, Huey RB, Deutsch CA (2008) Putting the heat on tropical animals. Science 320:1296-1297. doi: 10.1126/science.1159328

Trzcinski MK, Srivastava DS, Corbara B, et al (2016) The effects of food web structure on ecosystem function exceeds those of precipitation. J Anim Ecol 85:1147-1160. doi:

$10.1111 / 1365-2656.12538$

Wallestein M, Hall E (2012) A trait-based framwork for predicting when and where microbial adaptation to climate change will affect ecosystem functionning. Biogeochemistry 109:35-47

Wymore AS, Compson ZG, Liu CM, et al (2013) Contrasting rRNA gene abundance patterns for aquatic fungi and bacteria in response to leaf-litter chemistry. Freshw Sci 32:663-672. doi: 10.1899/12-122.1

Zhang Q, Wu J, Yang F, et al (2016) Alterations in soil microbial community composition and biomass following agricultural land use change. Sci Rep 6:srep36587. doi: $10.1038 /$ srep36587

Zotz G, Thomas V (1999) How much water is in the tank? Model calculations for two epiphytic bromeliads. Ann Bot 83:183-192. doi: 10.1006/anbo.1998.0809 
Table 1 Mixed effect model results for gross, net (corrected for DOM release) leaf litter mass loss and fungal:bacterial ratios for Goupia glabra and Platonia insignis leaves. The Hydroperiod is denoted by Hydro in the table, and Mesh denotes the decomposer treatment. * $\mathrm{p}<0.05, * * \mathrm{p}<0.01, * * * \mathrm{p}<0.001$. The symbol '-' denotes that the given variable was not significant in the model and thus the result is not shown.

\begin{tabular}{|c|c|c|c|c|c|c|c|c|c|c|}
\hline & & & $\begin{array}{l}\text { Gross } \\
\text { mposi }\end{array}$ & & & $\begin{array}{l}\text { ally-as } \\
\text { nposi }\end{array}$ & & & $\begin{array}{r}\text { gal:Bac } \\
\text { ratio }\end{array}$ & \\
\hline & & $F$ & $\mathrm{df}$ & $\mathrm{p}$ & $\mathrm{F}$ & $\mathrm{df}$ & $\mathrm{p}$ & $\mathrm{F}$ & $\mathrm{df}$ & $\mathrm{p}$ \\
\hline & Hydro & 61.2 & 5,86 & $* * *$ & 13.4 & 5,86 & $* * *$ & 2.81 & 4,15 & 0.06 \\
\hline & Mesh & 5.9 & 1,86 & * & 6.0 & 1,86 & $*$ & 6.30 & 1,15 & $*$ \\
\hline$\frac{5}{0}$ & $\begin{array}{l}\text { Hydro x } \\
\text { Mesh }\end{array}$ & 1.8 & 5,86 & 0.1 & 1.6 & 5,86 & 0.2 & 1.00 & 4,15 & 0.4 \\
\hline ర్ర & Cyphon & 15.4 & 1,86 & $* * *$ & 12.1 & 1,86 & $* * *$ & - & & - \\
\hline & Trentepohlia & 17.17 & 1,86 & $* * *$ & 15.8 & 1,86 & $* * *$ & - & & - \\
\hline & Hydro & 46.1 & 5,83 & $* * *$ & 10.5 & 5,84 & $* * *$ & 4.28 & 4,15 & $*$ \\
\hline$\cong$ & Mesh & 2.2 & 1,83 & 0.1 & 1.2 & 1,84 & 0.3 & 9.54 & 1,15 & $* *$ \\
\hline$\stackrel{\bar{\Xi}}{\Xi}$ & Hydro x & 0.7 & 5,83 & 0.6 & 1.3 & 5,84 & 0.3 & 1.85 & 4,15 & 0.2 \\
\hline$\frac{0}{0}$ & Cyphon & 7.7 & 1,83 & $* *$ & 7.2 & 1,84 & $* *$ & - & & - \\
\hline & Trentepohlia & 17.17 & 1,83 & $* * *$ & - & & - & - & & - \\
\hline
\end{tabular}


Table 2 Helmert's orthogonal contrasts results for the effect of hydroperiod (as factor) on gross leaf litter mass loss for Goupia glabra and Platonia insignis leaves. Contrast 1(C1) compared the mean of the dry control with the mean of all other levels of hydroperiod (dry control vs. wet control, $1_{56}, 2_{28}, 4_{14}, 8_{7}$ ). Contrast 2 (C2) compared the mean of the wet control with the mean of all experimental levels (wet control vs. 156, 228, $4_{14}, 8_{7}$ ). Contrast 3 (C3) compared the mean of the $8_{7}$ treatment with the mean of three other hydroperiods $\left(8_{7} v s .4_{14}\right.$, $\left.228,1_{56}\right)$. Contrast $4(\mathrm{C} 4)$ compared the mean of the $4_{14}$ treatment with the mean of longer dry periods $\left(4_{14}\right.$ vs. $\left.2_{28}, 1_{56}\right)$. Contrast 5 (C5) compared the mean of the $2_{28}$ treatment with the longest dry periods $\left(2_{28} v s .1_{56)}\right.$. $^{*} \mathrm{p}<0.05, * * \mathrm{p}<0.01, * * * \mathrm{p}<0.001$. The symbol '-' denotes that the given variable was not significant in the model and thus the result is not shown.

\begin{tabular}{|c|c|c|c|c|c|c|c|c|c|c|}
\hline & \multicolumn{4}{|c|}{ Goupia glabra } & & \multicolumn{4}{|c|}{ Platonia insignis } & \\
\hline & Value & SE & $\mathrm{df}$ & $\mathrm{t}$ & $\mathrm{p}$ & Value & SE & $\mathrm{df}$ & $\mathrm{t}$ & $\mathrm{p}$ \\
\hline $\mathrm{C} 1$ & -0.74 & 0.09 & 87 & -8.63 & $* * *$ & -0.72 & 0.09 & 84 & -7.96 & $* * *$ \\
\hline $\mathrm{C} 2$ & 0.27 & 0.09 & 87 & -3.12 & $* *$ & 0.19 & 0.09 & 84 & 2.08 & * \\
\hline $\mathrm{C} 3$ & 0.17 & 0.07 & 87 & 2.22 & $*$ & -0.13 & 0.08 & 84 & -1.78 & 0.08 \\
\hline $\mathrm{C} 4$ & -0.12 & 0.07 & 87 & 1.78 & 0.08 & -0.10 & 0.07 & 84 & -1.47 & 0.15 \\
\hline C5 & 0.02 & 0.06 & 84 & -0.39 & 0.7 & -0.04 & 0.06 & 43 & -0.74 & 0.5 \\
\hline
\end{tabular}




\section{FIGURE CAPTIONS}

Fig. 1 (a) Three leaf strips are shown for each leaf litter species (G. glabra and P. insignis), including two $1 \mathrm{x} 4 \mathrm{~cm}$ strips for mass loss assessment and one 1x5 cm strip for DNA analysis. (b) Coarse- and fine-mesh size enclosures. (c) A couple of experimental tubes inside a bromeliad well (wet phase) and outside (dry phase). (d) Experimental schedule with each cell corresponding to one unit of 7 days

Fig. 2 (a-b) Gross leaf litter mass loss (mean $\% \pm \mathrm{SE}$; $\mathrm{N}=9$ controls and $\mathrm{N}=18$ hydroperiod treatments) for the two leaf litter species, Goupia glabra (a) and Platonia insignis (b) in coarse (dark grey) and fine (light grey) mesh enclosures. Black dots are leaf litter mass losses (mean $\% \pm \mathrm{SE} ; \mathrm{N}=6$ ) due to DOM release, estimated from laboratory assays using antibiotics. Manipulations included two controls denoted by 'Drought' (0 days of immersion) and 'Wet' (112 days of immersion), and four hydroperiod treatments: one dry:wet cycle of 56:56 days (156), two cycles of 28 days $\left(2_{28}\right)$, four cycles of 14 days $\left(4_{14}\right)$, and eight cycles of 7 days $\left(8_{7}\right)$. (c-d) Biologically-assisted leaf litter mass loss (mean $\% \pm \mathrm{SE}$; $\mathrm{N}=9$ Wet control and $\mathrm{N}=18$ hydroperiod treatments) after correction for DOM release in G. glabra (c) and P. insignis (d) in coarse (dark grey) and fine (light grey) mesh enclosures. Bars marked with the same letter are not significantly different for Drought factor ( $p>0.05)$ according to Tukey's HSD test

Fig. 3 (a-b) Mean abundance of bacteria and fungi (number of gene copies $\pm S E ; N=3$ ) for Goupia glabra (a) and Platonia insignis (b) in coarse (dark grey) and fine (light grey) mesh enclosures. (c-d) Mean fungal:bacterial ratio ( $\pm \mathrm{SE} ; \mathrm{N}=3$ ) for G. glabra (c) and P. insignis (d). Mean fungal:bacterial ratio ( \pm SE) from freshly-fallen leaves of G. glabra $(0.006 \pm 0.0009)$ and $P$. insignis $(0.002 \pm 0.0005)$, measured from 3 samples each, may serve as baseline reference. Manipulation levels included one control denoted 'Wet' (112 days of immersion), 
and four drought treatments as in Fig. 2. Bars marked with the same letter are not significantly different for Drought factor ( $\mathrm{p}>0.05$ ) according to Tukey's HSD test 
Fig 1

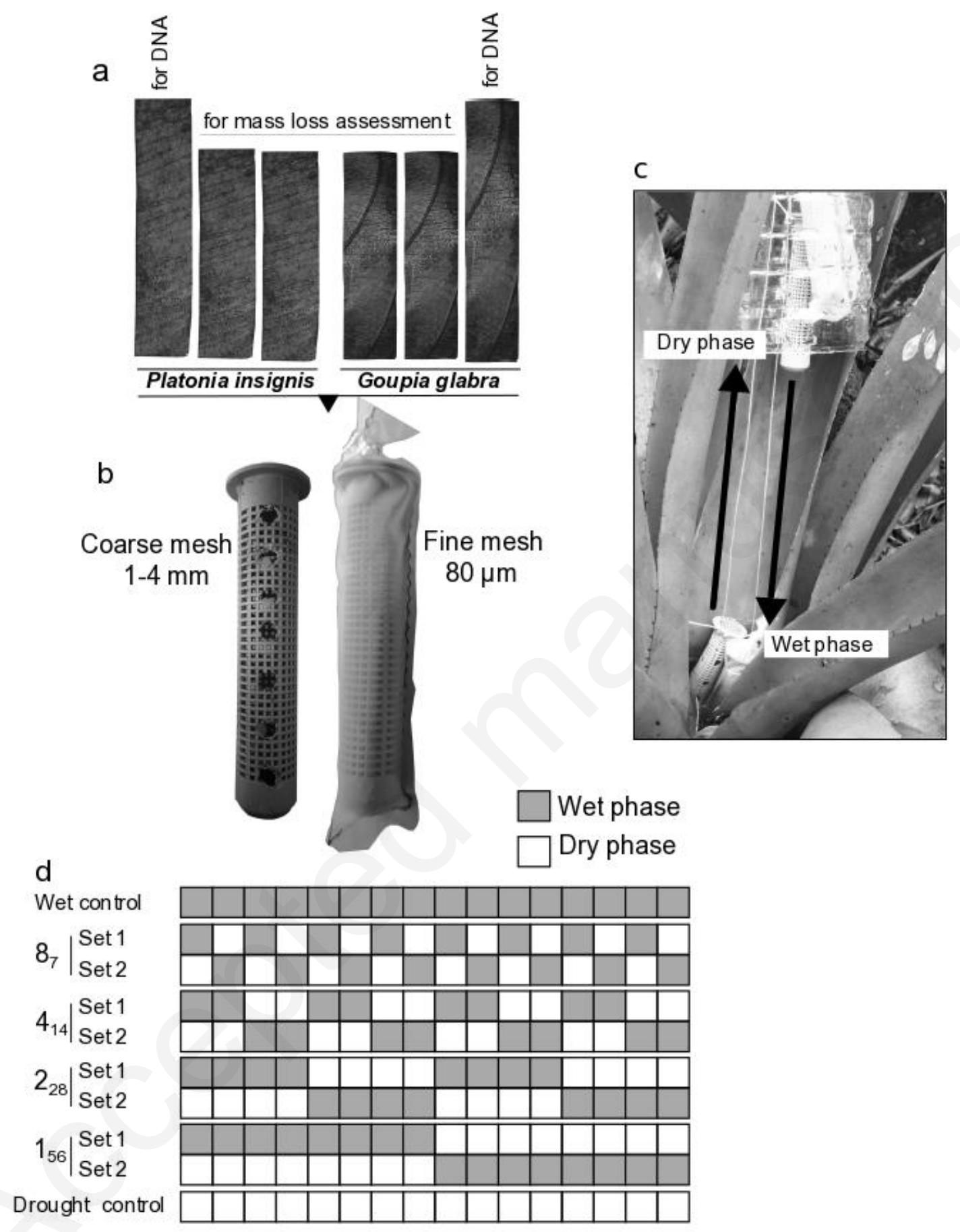


Fig 2
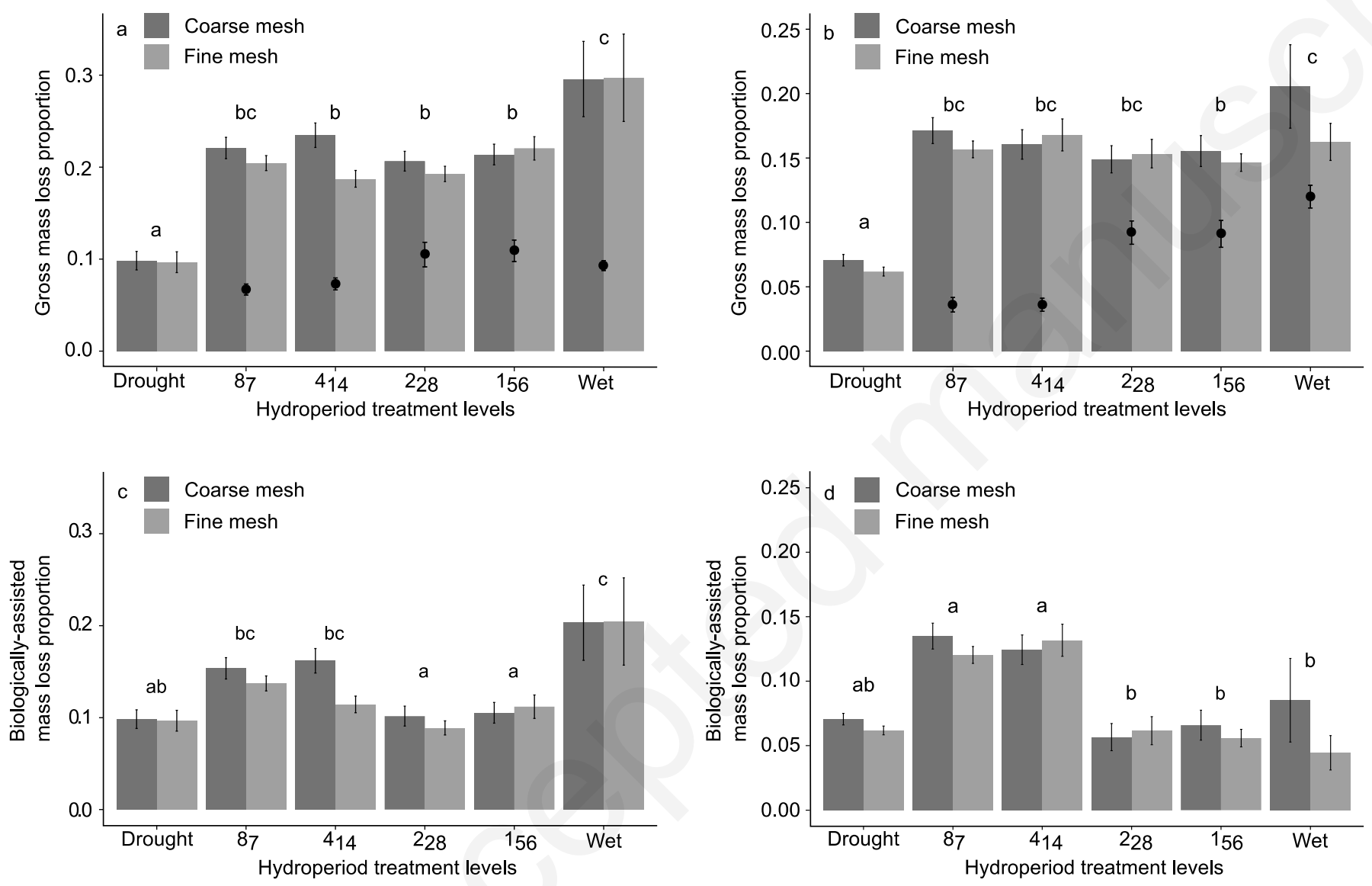
Fig 3
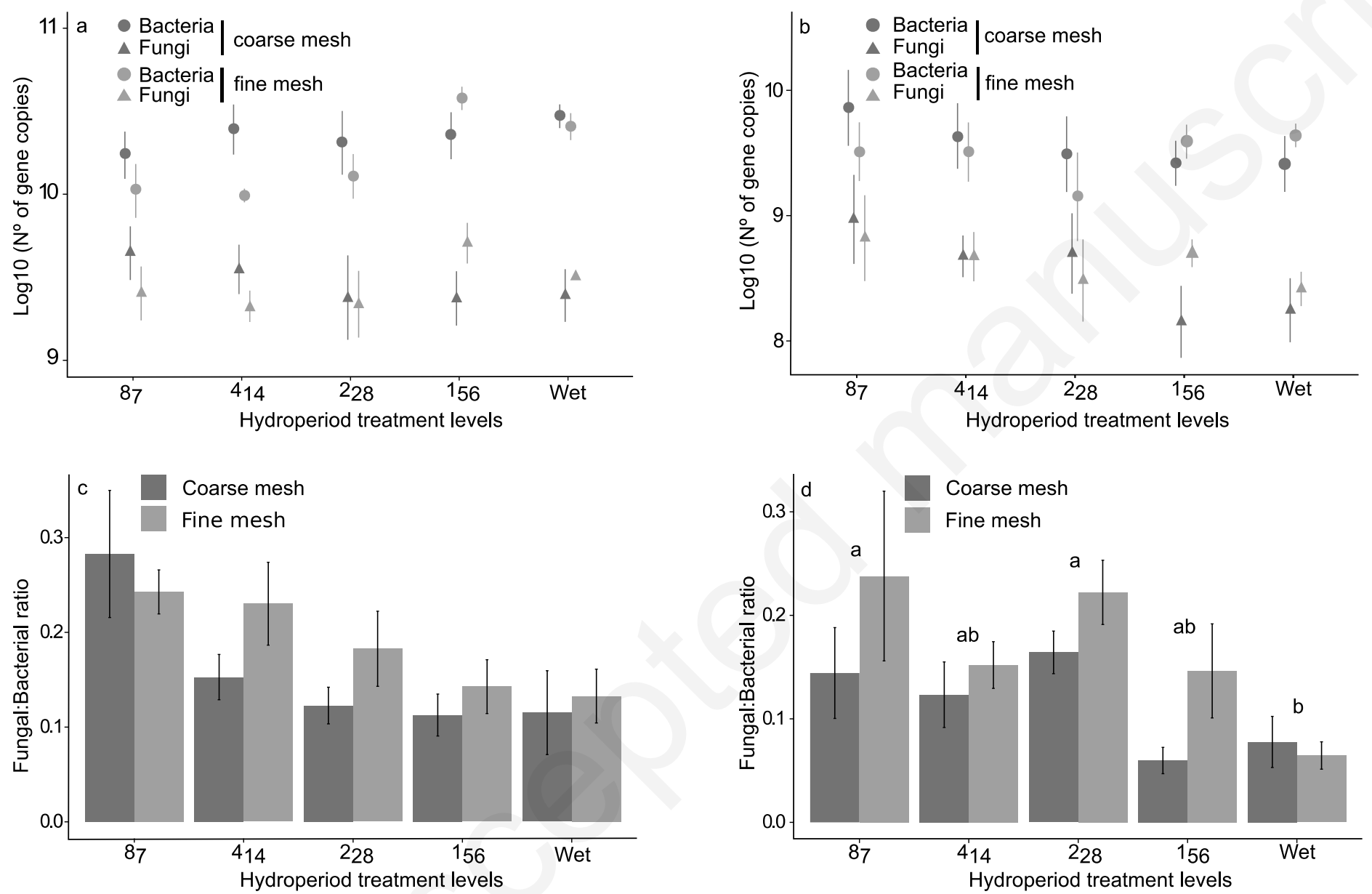